Check for updates

Cite this: RSC Adv., 2018, 8, 20025

\title{
Lithium sulfonate-grafted poly(vinylidenefluoride- hexafluoro propylene) ionomer as binder for lithium-ion batteries
}

\author{
Zhiqun Wang, ${ }^{a}$ Shaokang Tian, ${ }^{a}$ Shangda Li, ${ }^{a}$ Lei Li, (DD *ab Yimei Yin ${ }^{\mathrm{b}}$ and Zifeng Ma (D) ${ }^{\mathrm{b}}$ \\ Lithium sulfonate-grafted poly(vinylidenefluoride-hexafluoro propylene) P(VDF-HFP) ionomers are \\ synthesized through covalent attachment of taurine and used as binder for the $\mathrm{LiFePO}_{4}$ cathode of \\ lithium-ion batteries(LIBs). The incorporation of the ionomer binders will add ionic conducting channels \\ inside the electrodes, and prevent electrolyte depletion during rapid charge-discharge processes. It \\ leads to an improved performance of LIBs using the ionomer binders including cycling stability and rate \\ capability compared to that of LIBs using non-ionic binders (PVDF and PVDF-HFP). Therefore, the lithium \\ sulfonate-grafted P(VDF-HFP) ionomers offer a new route to develop high-power LIBs.
}

Received 10th March 2018

Accepted 27th April 2018

DOI: $10.1039 / \mathrm{c} 8 \mathrm{ra0} 2122 \mathrm{~h}$

rsc.li/rsc-advances electroactive materials and electrolytes, which reduces the polarization resistance and increases the ionic conductivity within the electrodes. Li et al. used polyacrylic acid (PAA) as binder to lower the polarization resistance of the $\mathrm{LiFePO}_{4}$ cathode. ${ }^{40}$ By the addition of lithiated perfluorinated sulfonic ionomers such as Nafion ${ }^{41,42}$ and Dow $^{43}$ to the lithium cathode, cycling stability at large current density of LIBs was improved. Shi et al. synthesized lithiated poly(perfluoroalkyl sulfonyl)imde (PFSILi) ionene and blended it with PVDF to make it as ionic binder for the $\mathrm{LiFePO}_{4} / \mathrm{C}$ cathode. ${ }^{44}$ The cathode with this ionic composite binder exhibited a higher rate capacity compared with the PVDF non-ionic binder. Chui et al. adopted lithiated perfluorosulfonate ionomer as the binder for $\operatorname{LiMn}_{2} \mathrm{O}_{4}$ cathodes. ${ }^{41}$ Wei et al. prepared the $\mathrm{LiFePO}_{4} / \mathrm{C}$ cathode with sulfonated polyether ether ketone with pendant lithiated fluorinated sulfonic groups (SPEEK-FSA-Li) as binder to reduce the $\mathrm{Li}^{+}$concentration polarization and electrolyte depletion during rapid charge-discharge processes. ${ }^{45}$

Since poly(vinylidenefluoride-hexafluoro propylene) (P(VDFHFP)) polymer has higher amorphousity and lower glass transition temperature $\left(T_{\mathrm{g}}\right)$, $\mathrm{Hu}$ et al. reported that the $\mathrm{LiFePO}_{4}$ cathode using P(VDF-HFP) as binder showed better electrochemical performance including cycling stability and rate capability compared to the $\mathrm{LiFePO}_{4}$ cathode using PVDF as binder. ${ }^{46}$ However, P(VDF-HFP) polymer still does not have intrinsic ionic functionality, so that it is difficult to improve rate performance of LIBs.

Herein, we synthesized lithium sulfonate-grafted P(VDFHFP) ionomers with different content of $\mathrm{Li}^{+}$and used them as binders for the $\mathrm{LiFePO}_{4}$ cathode of LIBs. It is well known that amine is easily grafted onto fluoropolymer main chains as functional groups owing to the strong polarity of C-F bonds. ${ }^{47,48}$ In our experiments, taurine, one of sulfur-containing amino acids, was directly grafted onto $\mathrm{P}(\mathrm{VDF}-\mathrm{HFP})$ polymer chains
${ }^{a}$ School of Chemistry and Chemical Engineering, Shanghai Key Lab of Electrical Insulation and Thermal Aging, Shanghai Jiao Tong University, Shanghai 200240, China.E-mail: lilei0323@sjtu.edu.cn

${ }^{b}$ Shanghai Electrochemical Energy Devices Research Center, School of Chemistry and Chemical Engineering, Shanghai Jiaotong University, Shanghai 200240, China 


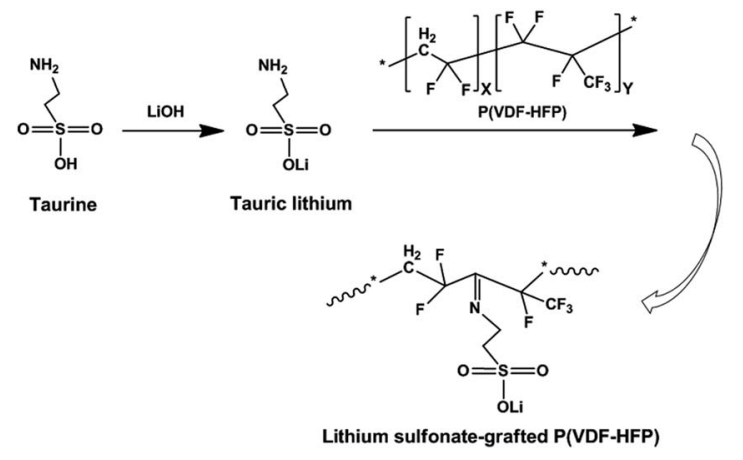

Scheme 1 Schematic illustration of synthesis route of lithium sulfonated grafted P(VDF-HFP).

through one reaction in solution (see Scheme 1). The content of $\mathrm{Li}^{+}$of the lithium sulfonate-grafted P(VDF-HFP) ionomers was controlled by various taurine feed contents. Electrochemical performance of these ionomers as binders for the $\mathrm{LiFePO}_{4}$ cathodes of LIBs were investigated by electrochemical impedance spectroscopy, charge-discharge testing, cycling voltammetry and $180^{\circ}$ peel testing. The performance of cathodes including cycling stability, rate capability and adhesion strength were improved compared to the cathodes using P(VDFHFP) as binders. To the best of our knowledge, it is the first time to report that the lithium sulfonate-grafted $\mathrm{P}(\mathrm{VDF}-\mathrm{HFP})$ ionomers were used as binders in LIBs.

\section{Experimental}

\section{Synthesis lithium sulfonate-grafted P(VDF-HFP)}

First, $4.0 \mathrm{~g}$ taurine and $0.768 \mathrm{~g} \mathrm{LiOH}(1: 1 \mathrm{~mole}$ ratio) were dissolved in $30 \mathrm{~mL}$ of deionized water, and stirred at $40{ }^{\circ} \mathrm{C}$ for $5 \mathrm{~h}$. After that, the solution was free-dried for $48 \mathrm{~h}$ to obtain tauric lithium. Second, $2.0 \mathrm{~g}$ P(VDF-HFP) $\left(M_{\mathrm{w}}=115000, X=9, Y=1\right.$ Solvay Solexis Inc.) polymer was added into $38.0 \mathrm{~g}$ dimethylacetamide (DMAC) solvent with magnetic stirring for $2 \mathrm{~h}$. Then desired amounts of tauric lithium and MgO (2:1 mole ratio) were added into the solution. In our experiments, the weight ratios of tauric lithium and $\mathrm{P}(\mathrm{VDF}-\mathrm{HFP})$ were kept at $5 \mathrm{wt} \%$, $15 \mathrm{wt} \%$ and $20 \mathrm{wt} \%$, respectively. The mixture was heated and kept at $100{ }^{\circ} \mathrm{C}$ for $10 \mathrm{~h}$ in argon atmosphere, and then cooled down to room temperature. After that, the product was precipitated from diethyl ether and washed by deionized water till the $\mathrm{pH}=7$. Finally, the lithium sulfonate-grafted $\mathrm{P}(\mathrm{VDF}-\mathrm{HFP})$ ionomer was dried at $60^{\circ} \mathrm{C}$ under vacuum overnight to remove the residual solvent. The content of $\mathrm{Li}^{+}$of the lithium sulfonategrafted $\mathrm{P}(\mathrm{VDF}-\mathrm{HFP})$ ionomers was determined by titration: the ionomers were kept in $1 \mathrm{M} \mathrm{HCl}$ aqueous solution for $72 \mathrm{~h}$ to substitute $\mathrm{Li}^{+}$by $\mathrm{H}^{+}$of ionomers, then soaked in $3.4 \mathrm{M} \mathrm{NaCl}$ aqueous solution for $30 \mathrm{~h}$ and finally back titrated with $0.5 \mathrm{M}$ $\mathrm{NaOH}$ using phenolphthalein as an indicator. The ionomers with the taurine feed content $5 \mathrm{wt} \%, 15 \mathrm{wt} \%$ and $20 \mathrm{wt} \%$ were denoted as grafted-P(VDF-HFP)-5, grafted-P(VDF-HFP)-15 and grafted$\mathrm{P}(\mathrm{VDF}-\mathrm{HFP})-20$, respectively.

\section{Characterization}

The chemical structure of the lithium sulfonate-grafted P(VDFHFP) was analysed by Fourier transform infrared spectroscopy (ATR-FTIR, Spectrum 100, Perkin Elmer, Inc., USA) with a wavenumber range of $4000-400 \mathrm{~cm}^{-1}$, and Nuclear magnetic resonance $\left({ }^{1} \mathrm{H}\right.$ NMR) spectra (BioSpin Corp., Germany) using a $400 \mathrm{MHz}$ spectrometer (AVANCE III HD $400 \mathrm{MHz}$ Bruker) in DMSO- $\mathrm{d}_{6}$ instrument at $25{ }^{\circ} \mathrm{C}$. X-Ray Photo Electron Spectroscopy (XPS) was performed using an X-ray photoelectron spectrometer (AXIS ULTRA DLD, Kratos Analytical Ltd., UK) with a monochromatic $\mathrm{Al} \mathrm{K} \alpha$ source $(1486.6 \mathrm{eV})$.

\section{Electrochemical measurements}

The working electrode of the lithium-ion battery was prepared by mixing $\mathrm{LiFePO}_{4}$ (Pylon Technologies Co., Ltd., China), Super $\mathrm{P}$ (Timcal Graphite \& Carbon, Switzerland) and the lithium sulfonate-grafted P(VDF-HFP) ionomers at a weight ratio of $80: 10: 10$ in $N$-methylpyrrolidone (NMP) solvent. The mixed slurry was coated on aluminium foil and dried under vacuum at $80{ }^{\circ} \mathrm{C}$ overnight. For comparison, the $\mathrm{LiFePO}_{4}$ cathode with $\mathrm{P}$ (VDF-HFP) $\left(M_{\mathrm{w}}=115000\right.$, Solvay Solexis Inc.) binders was prepared in the same way. The CR2025-type half-cells were assembled with lithium metal, Celgard 2400 separator, electrolyte $\left(1 \mathrm{M} \mathrm{LiPF}_{6}\right.$ in a $1: 1$ (wt: wt) EC/DMC) and the prepared working electrode. The test cells were assembled in an argonfilled glove box. Galvanostatic cycling was performed on Land CT2001A tester (Wuhan, China) between 2.4 and $4.3 \mathrm{~V}$ (Li vs. $\mathrm{Li}^{+}$). Electrochemical impedance spectroscopy (EIS) was accomplished with an Autolab frequency response analyzer from a frequency range of $0.01 \mathrm{~Hz}$ to $100 \mathrm{KHz}$. Cyclic voltammetry (CV) was measured between $2.4-4.3 \mathrm{~V}$ at a scanning rate of $0.2 \mathrm{mV} \mathrm{s}^{-1}$ by Autolab PGSTAT302 electro-chemical test system (Eco Chemie, the Netherlands) at room temperature.

\section{Adhesion characterization}

The adhesion strength of the binders between the coating of the $\mathrm{LiFePO}_{4}$ electrode and the $\mathrm{Al}$ current collector were measured by a 180 peeling test using an omnipotent electronic stress-strain tester (MTS, Criterion 43). The Al currents coated electrodes were cut to a strip of $9 \mathrm{~mm}$ width. The strip was pulled at a speed of $1.0 \mathrm{~cm} \mathrm{~min}^{-1}$.

\section{Results and discussion}

As shown in Scheme 1, two steps were used to obtain the lithium sulfonate-grafted P(VDF-HFP) ionomers: first, taurine was transformed to tauric lithium to increase its reactivity with $\mathrm{P}($ VDF-HFP) polymer; second, lithium sulfonate was directly grafted onto $\mathrm{P}(\mathrm{VDF}-\mathrm{HFP})$ polymer chains. There are four steps for tauric lithium grafted onto P(VDF-HFP) polymer (see Scheme 2). After dehydrofluorination of the HFP-VDF-HFP triad with amine from tauric lithium (Step 1), MgO allows to trap HF and regenerates the amine (tauric lithium Step 2). The formation of water occurs during the reaction. In Step 3, the amine from tauric lithium adds onto the $\mathrm{CF}=\mathrm{CH}$ double bond through a Michael addition reaction. Finally, the 


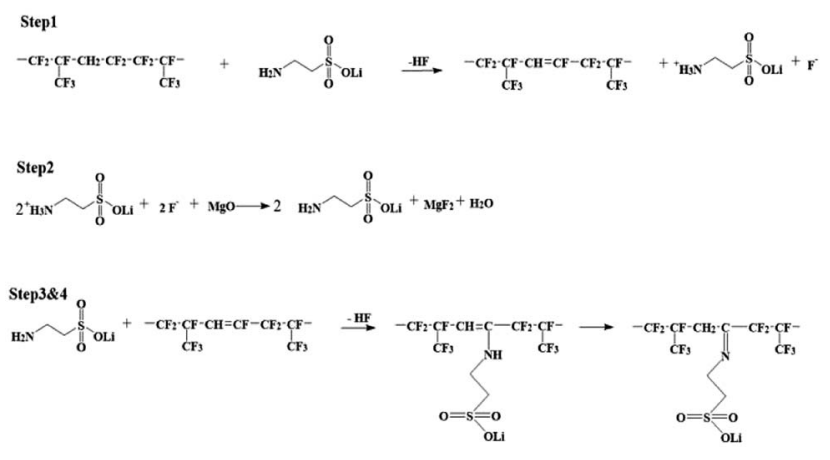

Scheme 2 Mechanism of tauric lithium onto P(VDF-HFP) polymer.

rearrangement leads to the formation of an imine (i.e. tauric lithium was grafted onto $\mathrm{P}(\mathrm{VDF}-\mathrm{HFP})$ polymer). ${ }^{48}$

Fig. 1a showed FTIR spectra of the P(VDF-HFP) polymer and the lithium sulfonate-grafted $\mathrm{P}(\mathrm{VDF}-\mathrm{HFP})$ ionomers. It can be found that there was a new characteristic peak at $1635 \mathrm{~cm}^{-1}$ attributed to the symmetric stretching vibration of $\mathrm{C}=\mathrm{N}$ in the lithium sulfonate-grafted ionomers compared to the $\mathrm{P}(\mathrm{VDF}-$ HFP) polymer. ${ }^{49}$ In addition, the characteristic peak at $1040 \mathrm{~cm}^{-1}$ belonging to the symmetric stretching vibration of $\mathrm{O}=\mathrm{S}=\mathrm{O}$ can also be clearly found. It indicated that tauric lithium was successfully grafted onto P(VDF-HFP) polymer chains. The peaks at 1178 and $1400 \mathrm{~cm}^{-1}$ were the stretching vibration of $\mathrm{CF}_{2}$ and $\mathrm{CH}_{2}$, respectively. ${ }^{50}$ It can be found that the intensity of both peaks of $\mathrm{CF}_{2}$ and $\mathrm{CH}_{2}$ reduced after grafting the tauric lithium.

To further verify this grafted reaction, the lithium sulfonated grafted $\mathrm{P}(\mathrm{VDF}-\mathrm{HFP})$ was infiltrated in $1 \mathrm{M} \mathrm{HCl}$ solution for $72 \mathrm{~h}$ to substitute $\mathrm{Li}^{+}$by $\mathrm{H}^{+}$. Then, the obtained sulfonic acid-grafted $\mathrm{P}$ (VDF-HFP) polymer was tested by ${ }^{1} \mathrm{H}$ NMR. Fig. $1 \mathrm{~b}$ shows ${ }^{1} \mathrm{H}$ NMR spectra of $\mathrm{P}(\mathrm{VDF}-\mathrm{HFP})$ polymer and the sulfonic acidgrafted P(VDF-HFP) with $15 \mathrm{wt} \%$ and $20 \mathrm{wt} \%$ contents of taurine. The new resonance at $7.7 \mathrm{ppm}$ can be assigned to hydroxyl proton of sulfonic acid group in the sulfonic acidgrafted P(VDF-HFP) compared to the P(VDF-HFP) polymer. ${ }^{51}$ It can also be found that the intensity of this new resonance at $7.7 \mathrm{ppm}$ increased with the increasing of the content of taurine. Both FTIR and ${ }^{1} \mathrm{H}$ NMR results demonstrated that tauric lithium was successfully grafted to $\mathrm{P}(\mathrm{VDF}-\mathrm{HFP})$ polymer in our experiments.

The content of $\mathrm{Li}^{+}$(i.e. $\mathrm{Li}^{+}$exchange capacity) in the lithium sulfonate-grafted $\mathrm{P}(\mathrm{VDF}-\mathrm{HFP})$ ionomers was determined quantitatively by titration method. Table 1 showed the theoretical $\mathrm{Li}^{+}$ exchange capacity and the measured $\mathrm{Li}^{+}$exchange capacity. Theoretical $\mathrm{Li}^{+}$exchange capacity of $5 \mathrm{wt} \%, 15 \mathrm{wt} \%$ and $20 \mathrm{wt} \%$ taurine feed content were $3.91 \times 10^{-4}, 1.17 \times 10^{-3}$ and $1.56 \times$ $10^{-3} \mathrm{mmol} \mathrm{g}^{-1}$ respectively. Measured $\mathrm{Li}^{+}$exchange capacity of $5 \mathrm{wt} \%, 15 \mathrm{wt} \%$ and $20 \mathrm{wt} \%$ taurine feed content were $3.81 \times$ $10^{-4}, 1.05 \times 10^{-3}$ and $1.25 \times 10^{-3} \mathrm{mmol} \mathrm{g}^{-1}$ respectively. The $\mathrm{Li}^{+}$exchange capacity was increased from $0.38 \mathrm{mmol} \mathrm{g}^{-1}$ from the ionomer with $5 \mathrm{wt} \%$ taurine feed content to $1.25 \mathrm{mmol} \mathrm{g}^{-1}$ with $20 \mathrm{wt} \%$ taurine feed content.

The electrochemical stability of the lithium-sulfonategrafted $\mathrm{P}(\mathrm{VDF}-\mathrm{HFP})$ binders in the $\mathrm{LiFePO}_{4}$ cathode was
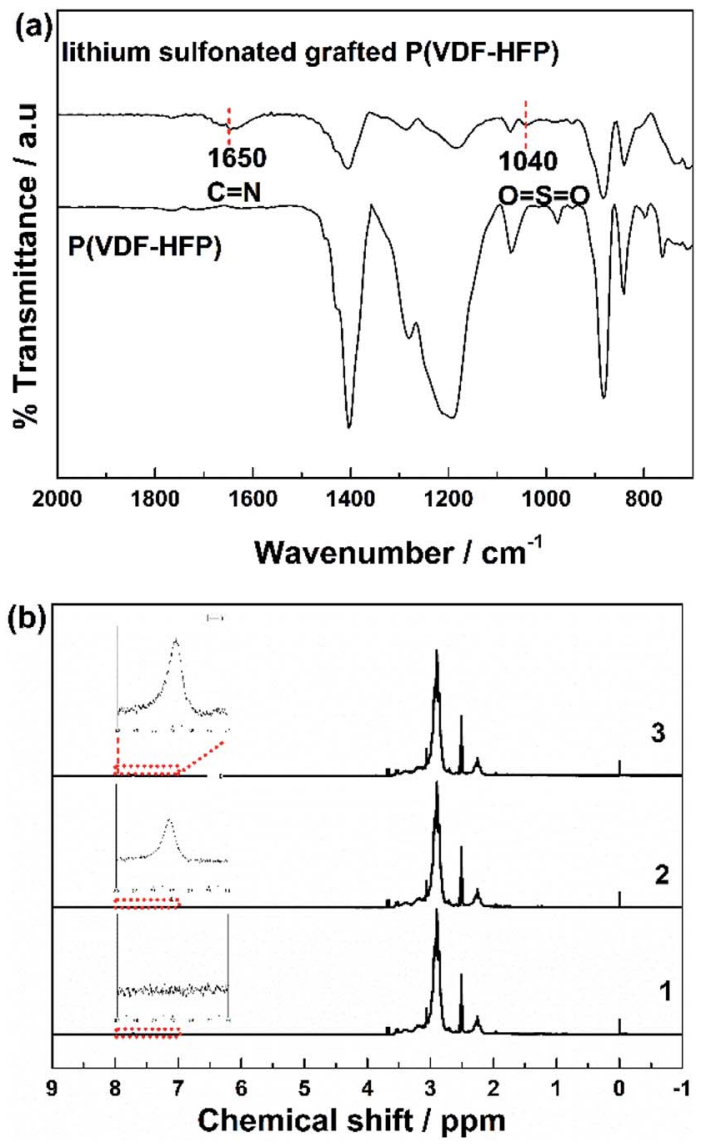

Fig. 1 (a) FTIR spectra of P(VDF-HFP) and lithium sulfonate-grafted P(VDF-HFP). (b) ${ }^{1} H$ NMR spectra of P(VDF-HFP) (1) and lithium sulfonate-grafted $\mathrm{P}(\mathrm{VDF}-\mathrm{HFP})$ with taurine feed content $15 \mathrm{wt} \%$ (2) and $20 \mathrm{wt} \%$ (3) in DMSO- $d_{6}$, respectively.

tested by cyclic voltammetry at room temperature. Fig. 2 showed the CV profiles of the $\mathrm{LiFePO}_{4}$ cathodes with the $\mathrm{P}(\mathrm{VDF}-\mathrm{HFP})$ and the grafted-P(VDF-HFP) binders at a scanning rate of $0.2 \mathrm{mV} \mathrm{s}^{-1}$ and room temperature. It can be found that there were a pair of oxidation and reduction peaks corresponding to $\mathrm{Fe}^{2+} / \mathrm{Fe}^{3+}$ redox couple for all the $\mathrm{LiFePO}_{4}$ electrodes. Compared to the electrode with P(VDF-HFP) binder, all the electrodes with the grafted-P(VDF-HFP) binders showed lower cathodic potential and higher anodic potential. Furthermore, the electrodes with the grafted-P(VDF-HFP) binders showed a smaller voltage difference between the oxidation and reduction peak potential than that of the electrode with $\mathrm{P}(\mathrm{VDF}-\mathrm{HFP})$ binder. The voltage differences ranked from $\mathrm{P}(\mathrm{VDF}-\mathrm{HFP})(0.95 \mathrm{~V})>$ grafted-P(VDFHFP $)-5(0.88 \mathrm{~V})>$ grafted-P(VDF-HFP)-15 $(0.83 \mathrm{~V})>$ grafted$\mathrm{P}(\mathrm{VDF}-\mathrm{HFP})-20(0.65 \mathrm{~V})$, which indicated that the electrodes with the grafted-P(VDF-HFP) binders will reduce the electrochemical polarization. In addition, the electrode with the grafted-P(VDF-HFP)-20 binder had the lowest electrochemical polarization among all the electrodes.

The cycling performance of the $\mathrm{LiFePO}_{4}$ electrodes with the $\mathrm{P}(\mathrm{VDF}-\mathrm{HFP})$ and grafted-P(VDF-HFP) binders were shown in Fig. 3. The cells were cycled at 1C under constant current conditions at room temperature. Fig. 3a showed the initial 
Table 1 Exchange capacity of lithium sulfonated-grafted P(VDF-HFP)

\begin{tabular}{|c|c|c|}
\hline Taurine feed content ${ }^{a}(\mathrm{wt} \%)$ & Theoretical $\mathrm{Li}^{+}$exchange capacity ${ }^{b}\left(\mathrm{mmol} \mathrm{g}^{-1}\right)$ & $\begin{array}{l}\text { Measured } \mathrm{Li}^{+} \text {exchange } \\
\text { capacity }\left(\mathrm{mmol} \mathrm{g}^{-1}\right)\end{array}$ \\
\hline 5 & $3.91 \times 10^{-4}$ & $3.81 \times 10^{-4}$ \\
\hline 15 & $1.17 \times 10^{-3}$ & $1.05 \times 10^{-3}$ \\
\hline 20 & $1.56 \times 10^{-3}$ & $1.25 \times 10^{-3}$ \\
\hline
\end{tabular}

charge and discharge curves of the $\mathrm{LiFePO}_{4}$ electrodes with different binders. It was clear that all the electrodes with the grafted-P(VDF-HFP) binders showed a higher discharge plateau potential and a lower charge plateau potential than that of the electrodes with the $\mathrm{P}(\mathrm{VDF}-\mathrm{HFP})$ binder. The similar results have also been reported in other ionomers as binders for LIBs. ${ }^{13-15}$ As shown in Fig. 3b, it was obvious that the cycling performance of the electrodes with the grafted-P(VDF-HFP) binders were better than that of the electrode with the P(VDF-HFP) binder. The capacity fading of the electrode with the $\mathrm{P}(\mathrm{VDF}-\mathrm{HFP})$ binder was severe, and the discharge specific capacity declined from 145.7 to $99.0 \mathrm{~mA} \mathrm{~h} \mathrm{~g}^{-1}$ (capacity retention: $67.9 \%$ ) after $50^{\text {th }}$ cycles. For the electrodes with the grafted-P(VDF-HFP) binders after $50^{\text {th }}$ cycles, the capacity decreased to $118.9 \mathrm{~mA} \mathrm{~h} \mathrm{~g}^{-1}$ (capacity retention: $79.8 \%$ ), $132.8 \mathrm{~mA} \mathrm{~h} \mathrm{~g}^{-1}$ (capacity retention: $89.0 \%$ ), and $140 \mathrm{~mA} \mathrm{~h} \mathrm{~g}^{-1}$ (capacity retention: $92.0 \%$ ) for grafted-P(VDFHFP)-5 binder, grafted-P(VDF-HFP)-15 binder and grafted$\mathrm{P}($ VDF-HFP)-20 binder, respectively.

Fig. 4 showed the rate performance of the electrodes with different binders at various discharge currents ranging from 0.5 $\mathrm{C}$ to $4 \mathrm{C}$. As expected, the discharge specific capacity of all the electrodes gradually decreased with the increasing discharge current density (i.e. rate). Compared to the electrode with $\mathrm{P}($ VDF-HFP) binder, however, all the electrodes with the grafted$\mathrm{P}($ VDF-HFP) binders showed lower decrease in capacity, especially at higher rates. For example, at $4 \mathrm{C}$ as shown in Fig. 4, the discharge specific capacity of the electrodes with the grafted binders (grafted-P(VDF-HFP)-5 binder: $36.5 \mathrm{~mA} \mathrm{~h} \mathrm{~g}^{-1}$, graftedP(VDF-HFP)-15: $78.8 \mathrm{~mA} \quad \mathrm{~h} \quad \mathrm{~g}^{-1}$, grafted-P(VDF-HFP)-20:

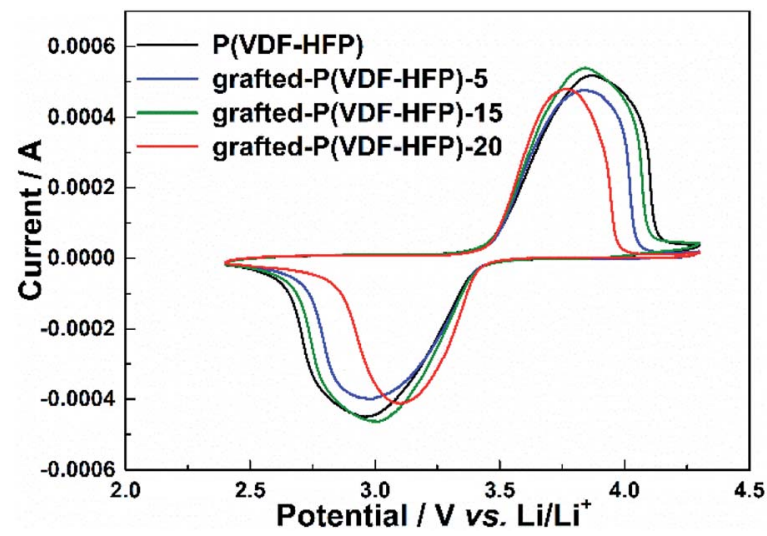

Fig. 2 Cyclic voltammograms of the $\mathrm{LiFePO}_{4}$ electrodes with $\mathrm{P}(\mathrm{VDF}$ $\mathrm{HFP}$ ) and lithium sulfonate-grafted P(VDF-HFP) binders at the scanning rate of $0.2 \mathrm{mV} \mathrm{s}^{-1}$ and room temperature.
95.9 $\mathrm{mA} \mathrm{h} \mathrm{g}^{-1}$ ) were higher than that of the electrode with $\mathrm{P}(\mathrm{VDF}-\mathrm{HFP})$ binder $\left(24.7 \mathrm{~mA} \mathrm{~h}^{-1}\right)$. It indicated that the electrodes with the grafted-P(VDF-HFP) binders showed higher rate capability than that of electrode with the P(VDF-HFP) binder. For the grafted binders, the rate performance of the electrodes increases with the increasing content of $\mathrm{Li}^{+}$(i.e. $\mathrm{Li}^{+}$exchange capacity) of the lithium sulfonate-grafted $\mathrm{P}(\mathrm{VDF}-\mathrm{HFP})$ ionomers. And the electrode with the grafted-P(VDF-HFP)-20 binder exhibited the best rate performance among all the electrodes. Due to P(VDF-HFP) binder does not have intrinsic ionic functionality, it will lead to salt concentration polarization and/or salt depletion within the electrodes during high rate charging and discharging, and finally result in the poorer rate
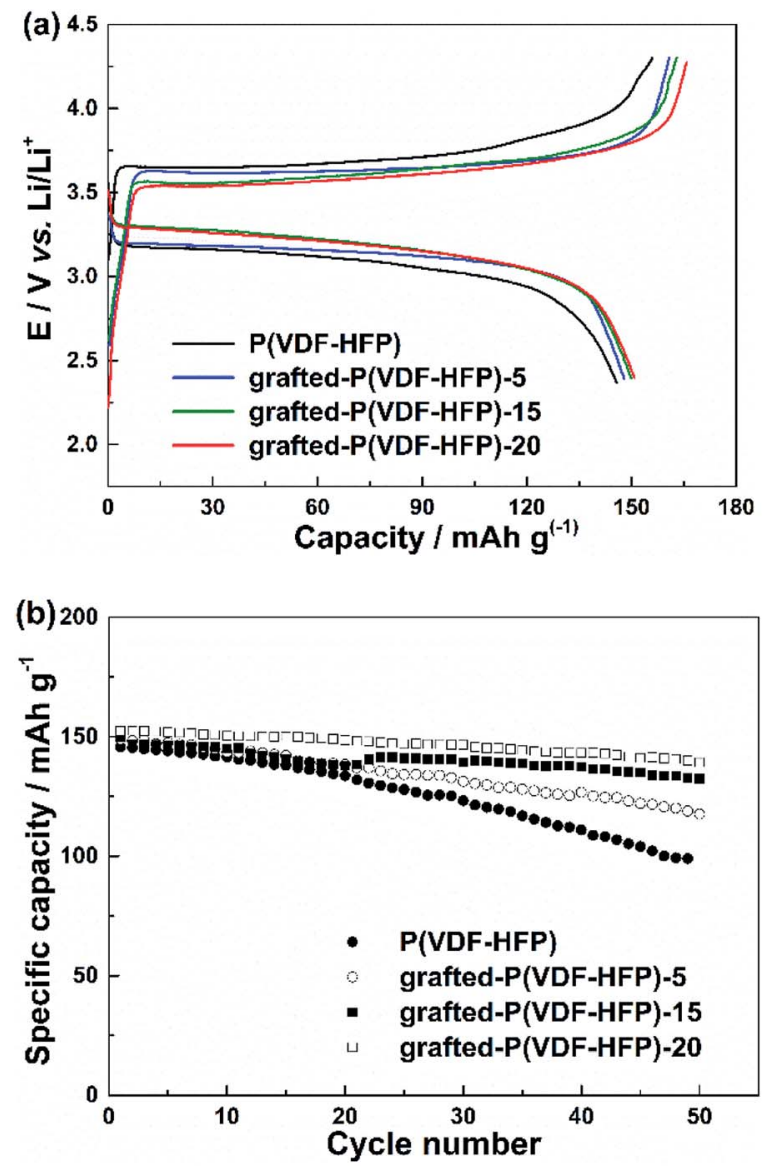

Fig. 3 (a) Initial charge and discharge profiles of the $\mathrm{LiFePO}_{4}$ electrodes with $\mathrm{P}(\mathrm{VDF}-\mathrm{HFP})$ and lithium sulfonate-grafted P(VDF-HFP) binders at room temperature and $1 \mathrm{C}$ rate. (b) Cycling performance of the $\mathrm{LiFePO}_{4}$ electrodes at room temperature and $1 \mathrm{C}$ rate. 


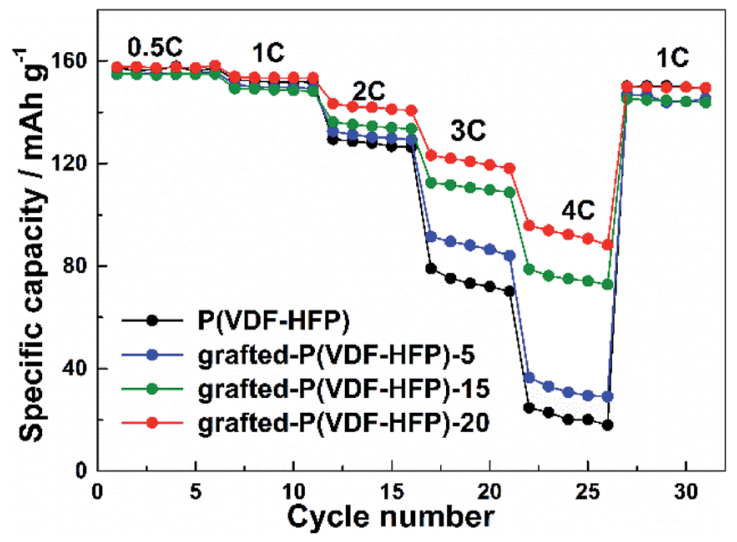

Fig. 4 Rate performance of the $\mathrm{LiFePO}_{4}$ electrodes with P(VDF-HFP) and lithium sulfonate-grafted P(VDF-HFP) binders.

capability of the electrodes. ${ }^{43}$ However, the lithium sulfonategrafted $\mathrm{P}(\mathrm{VDF}-\mathrm{HFP})$ ionomer can accommodate $\mathrm{Li}^{+}$ions, the loss of $\mathrm{Li}^{+}$ions in the electrolyte due to consumption via electrode reactions can be compensated (see Scheme 3). ${ }^{43}$ Therefore, the rate performance of the electrode with the ionomers will be enhanced.

Fig. 5 showed the cycling performance of the $\mathrm{LiFePO}_{4}$ electrodes at $60{ }^{\circ} \mathrm{C}$ and $1 \mathrm{C}$ rate. Normally, $\mathrm{LiPF}_{6}$-based electrolytes at higher temperature $\left(>50{ }^{\circ} \mathrm{C}\right)$ will result in thermal decomposition of $\mathrm{LiPF}_{6}$ to form $\mathrm{LiF}, \mathrm{PF}_{5}$ and $\mathrm{HF}$, which will lead to not only the decomposition of the electrolyte, but also increase the resistance of LIBs and finally bring about fading of the capacity. In addition, the iron element of $\mathrm{LiFePO}_{4}$ will tend towards dissolving in the electrolyte due to the presence of HF. These issues caused that both LIBs with $\mathrm{P}(\mathrm{VDF}-\mathrm{HFP})$ and grafted$\mathrm{P}$ (VDF-HFP) binders showed poor thermal stability at $60{ }^{\circ} \mathrm{C}$. However, the electrode with the grafted-P(VDF-HFP)-20 binder exhibited better performance compared to the electrode with $\mathrm{P}$ (VDF-HFP) binder (as shown in Fig. 5). In addition, XPS measurements was carried out to verify the stability of grafted$\mathrm{P}(\mathrm{VDF}-\mathrm{HFP})$ binders after the cycling test at higher temperature. As shown in Fig. 6a, N1s spectra of the $\mathrm{LiFePO}_{4}$ electrode with lithium sulfonate-grafted $\mathrm{P}(\mathrm{VDF}-\mathrm{HFP})$ binder before cycling test can be fitted into three peaks at $398.2,399.5,401.0 \mathrm{eV}$,

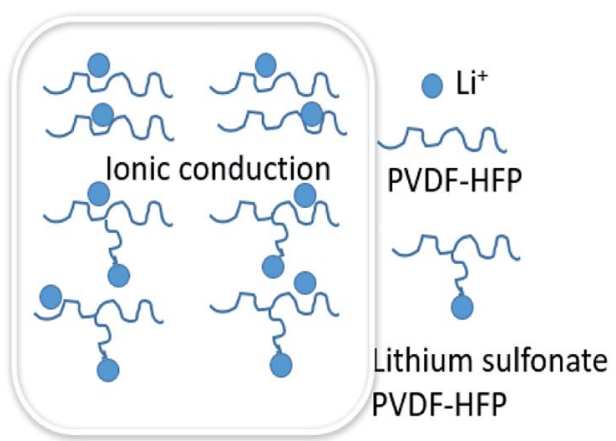

Scheme 3 Illustration of a possible mechanism for Li-ion transport in the electrodes with P(VDF-HFP) and lithium sulfonate-grafted P(VDFHFP) binders.

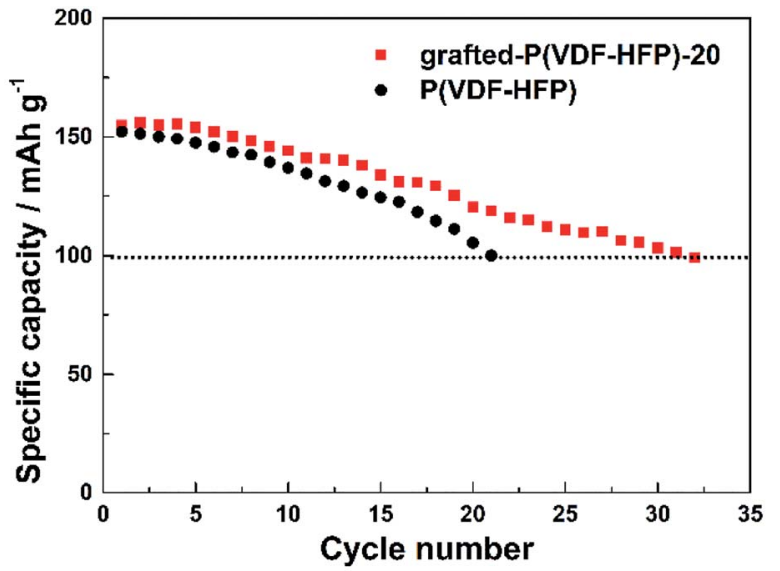

Fig. 5 Cycling performance of the $\mathrm{LiFePO}_{4}$ electrodes with P(VDFHFP) and lithium sulfonate-grafted P(VDF-HFP) binders at $60^{\circ} \mathrm{C}$ and $1 \mathrm{C}$ rate.

corresponding to pyridine-like, pyrrole-like and quaternary-like nitrogen, respectively. ${ }^{52}$ Compared to the electrode before cycling test, we can not find any change for the electrode after cycling test (see Fig. 6). These results indicated that the grafted$\mathrm{P}($ VDF-HFP) binder was stable during the cycling test, even at higher temperature. The reason maybe the $\mathrm{C}=\mathrm{N}$ double bond in the grafted-P(VDF-HFP) polymer was highly reactive towards nucleophiles due to the polarization by both $\mathrm{CF}_{3}$ and $\mathrm{CF}\left(\mathrm{CF}_{3}\right)$ perfluoroalkyl groups.

Fig. 7a showed the EIS curves of the $\mathrm{LiFePO}_{4}$ electrodes with the $\mathrm{P}(\mathrm{VDF}-\mathrm{HFP})$ and grafted-P(VDF-HFP) binders. An intercept at $Z_{\mathrm{re}}$-axis in the high frequency corresponds to the ohmic resistance $\left(R_{\mathrm{S}}\right)$. The semicircle in the middle frequency range was attributed to the charge-transfer reaction resistance $\left(R_{\mathrm{ct}}\right)$ in the cathode-electrolyte interface. The straight line in the lower frequency region represented the Warburg impedance $(W)$, which was associated with $\mathrm{Li}^{+}$diffusion in the $\mathrm{LiFePO}_{4} / \mathrm{C}$ cathode. A simplified equivalent circuit was constructed to analyse the impedance spectra in Fig. 7a by ZSimpWin V 3.1 program. The lithium ion diffusion coefficient $\left(D_{\mathrm{Li}}\right)$ can be calculated from the formula as following: ${ }^{53}$

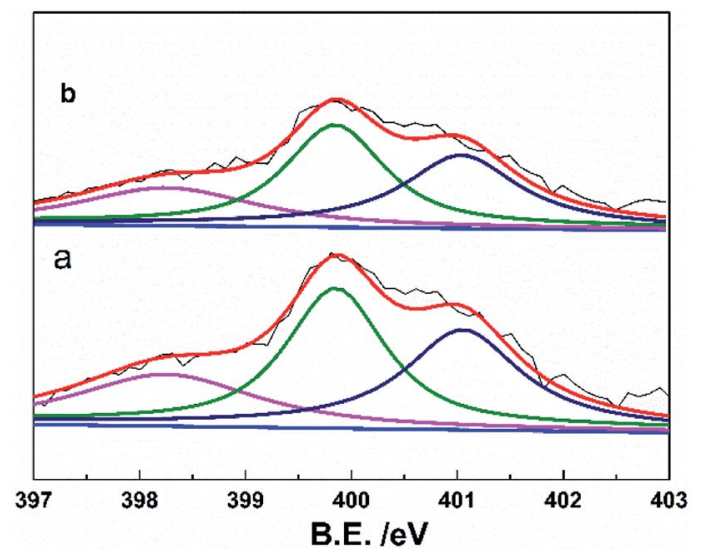

Fig. 6 XPS of N1s of the $\mathrm{LiFePO}_{4}$ electrodes with lithium sulfonategrafted P(VDF-HFP) binder before cycling test (a) and (b) after cycling test $\left(32^{\text {nd }}\right.$ cycle) at $60^{\circ} \mathrm{C}$ and $1 \mathrm{C}$ rate. 

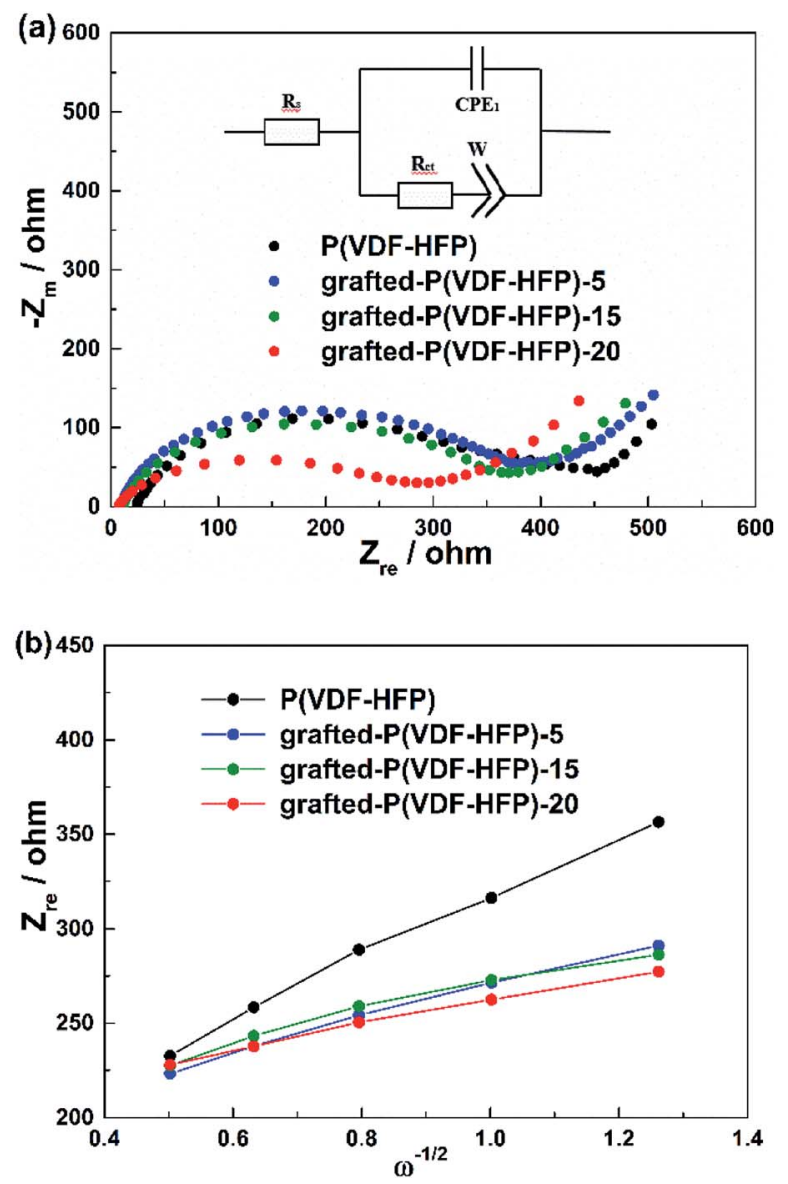

Fig. 7 (a) EIS results of the $\mathrm{LiFePO}_{4}$ electrodes with $\mathrm{P}(\mathrm{VDF}-\mathrm{HFP})$ and lithium sulfonate-grafted $\mathrm{P}(\mathrm{VDF}-\mathrm{HFP})$ binders at frequencies from $0.01 \mathrm{~Hz}$ to $100 \mathrm{kHz}$. (b) Plots of $Z^{\prime}-\omega^{-1 / 2}$ circuit.

$$
\begin{gathered}
D=\frac{R^{2} T^{2}}{2 A^{2} n^{4} F^{4} C^{2} \sigma^{2}} \\
Z^{\prime}=R_{\mathrm{e}}+R_{\mathrm{f}}+R_{\mathrm{ct}}+\sigma_{\mathrm{w}} W^{-1 / 2}
\end{gathered}
$$

herein $A$ is the surface area of the electrode, $F$ is the Faraday constant, $C$ is the concentration of lithium ion in the electrode, $n$ is the number of electrons per molecule during oxidization, $R$ is the gas constant, $T$ is the room temperature, $\sigma$ is the Warburg factor which can be obtained from the line of $Z^{\prime}-\omega^{-1 / 2}$ (shown in Fig. 7b). The calculated lithium diffusion coefficient for the electrodes with different binders were listed in Table 2 according to the above formula. From Table 2, it can be found that the electrodes with the grafted-P(VDF-HFP) binders showed higher lithium diffusion capability (i.e. higher $D_{\mathrm{Li}}$ value) than that of the electrode with $\mathrm{P}(\mathrm{VDF}-\mathrm{HFP})$ binder. It can be attributed to the lithium sulfonate-grafted $\mathrm{P}(\mathrm{VDF}-\mathrm{HFP})$ ionomer within the electrode will increase the migration number of $\mathrm{Li}^{+}$during the charge and discharge processes. And the electrode with the grafted-P(VDF-HFP)-20 binder exhibited the highest lithium diffusion capability among all the electrodes.

The adhesion ability between current collector and active material was a vital factor to choose suitable binder. In our
Table 2 Impedance parameters derived using equivalent circuit model and lithium diffusion coefficient for different binders of $\mathrm{LiFePO}_{4} / \mathrm{C}$ cathode

\begin{tabular}{lccc}
\hline Binders & $R_{\mathrm{s}}(\Omega)$ & $R_{\mathrm{ct}}(\Omega)$ & $D_{\mathrm{Li}}\left(\mathrm{cm} \mathrm{s}^{-1}\right)$ \\
\hline P(VDF-HFP) & 22.52 & 365.1 & $1.83 \times 10^{-14}$ \\
Grafted-P(VDF-HFP)-5 & 9.663 & 342.0 & $6.05 \times 10^{-14}$ \\
Grafted-P(VDF-HFP)-15 & 10.69 & 329.1 & $8.11 \times 10^{-14}$ \\
Grafted-P(VDF-HFP)-20 & 4.43 & 285.0 & $1.14 \times 10^{-13}$
\end{tabular}

experiments, 180 peeling test was employed to evaluate the adhesion strength between the coating electrode and the $\mathrm{Al}$ current. Since the electrode with the grafted-P(VDF-HFP)-20 binder showed the best electrochemical performance among all the electrodes based on the above-mentioned results, we further measured the adhesion ability of this electrode. The peeling strength of the electrodes with the P(VDF-HFP), grafted-P(VDF-HFP)-20 binders and PVDF are $0.96 \pm 0.01 \mathrm{~N}$, $1.22 \pm 0.01 \mathrm{~N}$ and $0.4 \mathrm{~N} \pm 0.01 \mathrm{~N}$, respectively. The result indicated that the adhesion of the electrode with the graftedP(VDF-HFP)-20 binder was stronger than that of the electrode with the $\mathrm{P}(\mathrm{VDF}-\mathrm{HFP})$ binder and PVDF.

\section{Conclusion}

In this work, we successfully synthesized the lithium sulfonategrafted $\mathrm{P}(\mathrm{VDF}-\mathrm{HFP})$ ionomers with different content of $\mathrm{Li}^{+}$ through the attachment of taurine, and used them as binders of the electrodes in LIBs and $\mathrm{Li}-\mathrm{S}$ batteries. The results have proved that the lithium sulfonate-grafted $\mathrm{P}(\mathrm{VDF}-\mathrm{HFP})$ ionomers exhibited good electrochemical performance as binders for less resistance SEI film and faster charge transfer during chargedischarge process. The binders containing lithium ionomers increased the available amount of lithium ions in the composite electrodes, resulting in the improvement of rate capability of LIBs. Considering taurine was ubiquitously distributed in animal tissues and can be chemically synthesized at low cost, we believe that the lithium sulfonate-grafted P(VDF-HFP) ionomers will be cheap and available. Therefore, the lithium sulfonate-grafted $\mathrm{P}(\mathrm{VDF}-\mathrm{HFP})$ ionomers offer a new route to improve electrochemical performance of batteries.

\section{Conflicts of interest}

There are no conflicts to declare.

\section{Acknowledgements}

This work was supported by the National Key R\&D Program of China (2016YFB0901505) and the Science and Technology Commission of Shanghai Municipality (14DZ2250800).

\section{References}

1 M. Doyle, M. E. Lewittes, M. G. Roelofs and S. A. Perusich, J. Mater. Chem. A, 2001, 105, 9387-9394. 
2 T.-H. Kim, J.-S. Park, S. K. Chang, S. Choi, J. H. Ryu and H.-K. Song, Adv. Energy Mater., 2012, 2, 860-872.

3 F. Caruso, Adv. Mater., 2001, 13, 11-22.

4 Y. Wang, A. S. Angelatos and F. Caruso, Chem. Mater., 2007, 20, 848-858.

5 W. Pu, X. He, L. Wang, C. Jiang and C. Wan, J. Membr. Sci., 2006, 272, 11-14.

6 K. M. Kim, N.-G. Park, K. S. Ryu and S. H. Chang, Electrochim. Acta, 2006, 51, 5636-5644.

7 W. G. Moon, G.-P. Kim, M. Lee, H. D. Song and J. Yi, ACS Appl. Mater. Interfaces, 2015, 7, 3503-3511.

8 Y.-H. Huang and J. B. Goodenough, Chem. Mater., 2008, 20, 7237-7241.

9 Z. Cai, Y. Liu, S. Liu, L. Li and Y. Zhang, Energy Environ. Sci., 2012, 5, 5690-5693.

$10 \mathrm{~J}$. Taracson and M. Armand, Nature, 2001, 414, 359-367.

11 S. W. Oh, S. T. Myung, S. M. Oh, K. H. Oh, K. Amine, B. Scrosati and Y. K. Sun, Adv. Mater., 2010, 22, 4842-4845.

12 M. Armand and J.-M. Tarascon, Nature, 2008, 451, 652-657.

13 H. Chen, T. N. Cong, W. Yang, C. Tan, Y. Li and Y. Ding, Prog. Mater. Sci., 2009, 19, 291-312.

14 W. Navarrini, B. Scrosati, S. Panero, A. Ghielmi, A. Sanguineti and G. Geniram, J. Power Sources, 2008, 178, 783-788.

15 S. Hu, Y. Li, J. Yin, H. Wang, X. Yuan and Q. Li, Chem. Eng. J., 2014, 237, 497-502.

16 P. A. Johns, M. R. Roberts, Y. Wakizaka, J. H. Sanders and J. R. Owen, Electrochem. Commun., 2009, 11, 2089-2092.

17 B. D. Assresahegn and D. Bélanger, J. Power Sources, 2017, 345, 190-201.

18 N. Jäckel, V. Dargel, N. Shpigel, S. Sigalov, M. D. Levi, L. Daikhin, D. Aurbach and V. Presser, J. Power Sources, 2017, 371, 162-166.

19 D. Ji, H. Zhou, Y. Tong, J. Wang, M. Zhu, T. Chen and A. Yuan, Chem. Eng. J., 2016, 313, 1623-1632.

20 W. Porcher, S. Chazelle, A. Boulineau, N. Mariage, J. P. Alper, T. V. Rompaey, J. S. Bridel and C. Haon, J. Electrochem. Soc., 2017, 164, A3633-A3640.

21 Y. Shi, X. Zhou and G. Yu, Acc. Chem. Res., 2017, 50, 26422652.

22 W. Zeng, L. Wang, X. Peng, T. Liu, Y. Jiang, F. Qin, L. Hu, P. K. Chu, K. Huo and Y. Zhou, Adv. Energy Mater., 2018, 1702314.

23 S. Choi, T. W. Kwon, A. Coskun and J. W. Choi, Science, 2017, 357, 279-283.

24 Y. Liu, Z. Tai, T. Zhou, V. Sencadas, J. Zhang, L. Zhang, K. Konstantinov, Z. Guo and H. K. Liu, Adv. Mater., 2017, 29, 1703028.

25 W. Long, B. Fang, A. Ignaszak, Z. Wu, Y. J. Wang and D. Wilkinson, Chem. Soc. Rev., 2017, 46, 7176-7190.

26 E. Peled, M. Goor, I. Schektman, T. Mukra, Y. Shoval and D. Golodnitsky, J. Electrochem. Soc., 2017, 164, A5001-A5007.

27 G. Xu, Q. B. Yan, A. Kushima, X. Zhang, J. Pan and J. Li, Nano Energy, 2017, 31, 568-574.

28 M. Ling, L. Zhang, T. Zheng, J. Feng, J. Guo, L. Mai and G. Liu, Nano Energy, 2017, 38, 82-90.
29 Q. Pang, X. Liang, C. Y. Kwok, J. Kulisch and L. F. Nazar, Adv. Energy Mater., 2017, 7, 1601630.

30 C. Wei, T. Lei, T. Qian, W. Lv, W. He, C. Wu, X. Liu, J. Liu, B. Chen and C. Yan, Adv. Energy Mater., 2018, 1702889.

31 C. Wei, Q. Tao, X. Jie, X. Na, X. Liu, L. Jie, J. Zhou, X. Shen, T. Yang and C. Yu, Adv. Mater., 2017, 29, 1605160.

32 H. M. Kim, J. Y. Hwang, D. Aurbach and Y. K. Sun, J. Phys. Chem. Lett., 2017, 8, 5331-5337.

33 Y. N. Liu, Q. Zhang, J. Lai, S. Qi, C. An, Y. Lu, X. Duan, W. Pang, D. Zhang and D. Sun, 2D Mater., 2018, 5, 1-8.

34 J. Pang, A. Bachmatiuk, L. Fu, R. G. Mendes, M. Libera, D. Placha, G. S. Martynková, B. Trzebicka, T. Gemming and J. Eckert, RSC Adv., 2015, 5, 60884-60891.

35 J. Pang, A. Bachmatiuk, Y. Yin, B. Trzebicka, L. Zhao, L. Fu, R. G. Mendes, T. Gemming, Z. Liu and M. H. Rummeli, Adv. Energy Mater., 2017, 1702093.

36 J. Pang, R. G. Mendes, P. S. Wrobel, M. D. Wlodarski, H. Q. Ta, L. Zhao, L. Giebeler, B. Trzebicka, T. Gemming and L. Fu, ACS Nano, 2017, 11, 1946-1956.

37 K. Olszowska, J. Pang, P. S. Wrobel, L. Zhao, H. Q. Ta, Z. Liu, B. Trzebicka, A. Bachmatiuk and M. H. Rummeli, Synth. Met., 2017, 234, 53-85.

38 K. Kato, F. N. Sayed, G. Babu and P. M. Ajayan, 2D Mater., 2018, 5, 1-8.

39 J. K. Papp, J. D. Forster, C. M. Burke, H. W. Kim, A. C. Luntz, R. M. Shelby, J. J. Urban and B. D. Mccloskey, J. Phys. Chem. Lett., 2017, 8, 1169-1174.

40 Z. P. Cai, Y. Liang, W. S. Li, L. D. Xing and Y. H. Liao, J. Power Sources, 2009, 189, 547-551.

41 K.-F. Chiu, S. H. Su, H.-J. Leu and Y. S. Chen, Electrochim. Acta, 2014, 117, 134-138.

42 H. Liang, X. Qiu, S. Zhang, W. Zhu and L. Chen, J. Appl. Electrochem., 2004, 34, 1211-1214.

43 J.-M. Oh, O. Geiculescu, D. DesMarteau and S. Creager, J. Electrochem. Soc., 2011, 158, A207-A214.

44 Q. Shi, L. Xue, Z. Wei, F. Liu, X. Du and D. D. DesMarteau, J. Mater. Chem. A, 2013, 1, 15016-15026.

45 Z. Wei, L. Xue, F. Nie, J. Sheng, Q. Shi and X. Zhao, J. Power Sources, 2014, 256, 28-31.

46 Y. S. Hu, R. Demir-Cakan, M. M. Titirici, J. O. Müller, R. Schlögl, M. Antonietti and J. Maier, Angew. Chem., Int. Ed., 2008, 47, 1645-1649.

47 W. Schmiegel, Macromol. Mater. Eng., 1979, 76, 39-65.

48 A. Taguet, B. Ameduri and A. Dufresne, Eur. Polym. J., 2006, 42, 2549-2561.

49 R. Zhou, W. Liu, Y. W. Leong, J. Xu and X. Lu, ACS Appl. Mater. Interfaces, 2015, 7, 16548-16557.

50 S. Wongchitphimon, R. Wang and R. Jiraratananon, J. Membr. Sci., 2011, 381, 183-191.

51 A. M. Flach, F. E. Johnson and I. Cabasso, Polym. Chem., 2013, 4, 3370-3376.

52 F. Zheng, Y. Yang and Q. Chen, Nat. Commun., 2014, 5, 52615361.

53 X. Y. Wang, H. Hao, J. L. Liu, T. Huang and A. S. Yu, Electrochim. Acta, 2011, 56, 4065-4069. 